\title{
Partial chemical and functional characterization of milk whey products obtained by different processes
}

\author{
Caracterização parcial química e funcional de produtos de soro de leite obtidos por diferentes processos
}

Fabiane La Flor ZIEGLER ${ }^{1 *}$, Georgia Alvares CASTRO로 , Yara Maria Franco MORENO², Vanessa OYA², Maria Marluce dos Santos VILELA ${ }^{2}$, Valdemiro Carlos SGARBIERI ${ }^{1}$

\begin{abstract}
Whey protein samples (S-1 to S-5) were tested in vivo and in vitro for nutritional properties and selected bioactivities. Weanling male Wistar rats fed modified AIN-93G (12 g protein. $\left.100 \mathrm{~g}^{-1}\right)$ diets for 21 days were used the in vivo studies. The nutritional parameters did not differ among the protein diets tested. Erythrocyte glutathione content was considered high and was higher for S-3, but liver glutathione was the same for all dietary groups. For S-3, cytokine secretion (IL-10 and TNF- $\alpha$ ) by human peripheral blood mononuclear cells (in RPMI-1640 medium) was higher in the absence of antigen than in the presence of BCG antigen. Interleukin-4 secretion was repressed in all treatments. The $\mathrm{IC}_{50}$, whey protein concentration required to inhibit $50 \%$ of the melanoma cell proliferation, was $2.68 \mathrm{mg} . \mathrm{mL}^{-1}$ of culture medium for the S-3 sample and $3.66 \mathrm{mg} \cdot \mathrm{mL}^{-1}$ for the S-2 sample. Based on these results, it was concluded that S-3 (whey protein concentrate enriched with TGF- $\beta$ and lactoferrin) produced better nutritional and immunological responses than the other products tested.

Keywords: whey proteins; nutritive value; immune modulation; glutathione; cytokines.
\end{abstract}

\section{Resumo}

Amostras de proteínas de soro de leite bovino (S-1 a S-5) foram testadas, in vivo e in vitro, para algumas propriedades nutricionais e bioatividades. Para os testes in vivo foram usados ratos da linhagem Wistar alimentados por 21 dias com dieta AIN-93G modificada quanto ao teor de proteína ( $12 \mathrm{~g}$ proteínas. $100 \mathrm{~g}^{-1}$ de dieta). Os parâmetros nutricionais medidos não diferiram entre as proteínas do soro de leite administradas através das dietas. O teor de glutationa nos eritrócitos foi mais elevado para o grupo alimentado com a amostra S-3. No grupo alimentado com S-3, a secreção de citocinas (IL-10 e TNF- $\alpha$ ) por células humanas mononucleares da circulação periférica, cultivadas no meio RPMI-1640, foi mais elevada na ausência do antígeno BCG do que em sua presença. A secreção de IL-4 foi inibida em todos os tratamentos. $\mathrm{O} \mathrm{IC}_{50}$ concentração de proteína de soro necessária para inibir $50 \%$ da proliferação de células de melanoma de camundongo foi 2,68 mg. $\mathrm{mL}^{-1}$ de meio de cultura para a amostra S-3 e 3,66 mg. $\mathrm{mL}^{-1}$ para a amostra S-2. Com base nesses resultados concluiu-se que a amostra S-3 (concentrado de proteína de soro enriquecida com TGF- $\beta$ e lactoferrina) produziu melhores respostas nutricional e imunológica quando comparada aos demais produtos testados.

Palavras-chave: proteína do soro; valor nutritivo; modulação imune; glutationa; citocina.

\section{Introduction}

In studies involving cell cultures, animal models, and clinical trials, whey proteins have shown to have protective properties against a number of pathological conditions. Tests have been performed on cancer mammary cells (LAURSEN; BRIAND; LYEKESFELDT, 1990), human leukemia cells (ROY et al., 2001), various types of cancer cells (HÄKANSON et al., 1995; SVENSSON et al., 2000). In addition, protective action in human prostate cells (KENT; HARPER; BOMSER, 2003), inhibitory action in mammary cells and in a rat mammary carcinoma model (BARUCHEL; VIAUX, 1996), inhibition of growth and metastasis of murine melanoma (BEZAULT et al., 1994), inhibition of hepatocellular carcinoma caused by Hepatitis C Virus (HCV) (IKEDA et al., 1998), inhibition of tumors in animal model systems (BOUNOUS; KONGSHAVN; GOLD, 1988; McINTOSH et al., 1995; McINTOSH; LE LEU,
2001; DIAS et al., 2006) have also been tested. Whey proteins have been used in treatments of metastatic mammal and liver carcinoma (KENNEDY et al., 1995), skin papiloma (GUSTAFSSON et al., 2004), and humans submitted to neck and head cancer surgery (CHMIEL, 1997) as well as on treatments for human glioblastoma transplanted to rats (FISCHER, 2004).

Studies with HIV-positive adults and children have also been carried out with some success (BOUNOUS et al., 1993; MORENO et al., 2005). Whey proteins have been reported to lower blood cholesterol (JACOBUCCI et al., 2001) and protect gastric mucosa against ulcerogenic drugs (ROSANELI et al., 2002; ROSANELI et al., 2004; MEZZAROBA et al., 2006).

Various physiological properties of milk whey proteins have been detailed in review articles (SGARBIERI, 1999; SGARBIERI,

\footnotetext{
Received 10/3/2010

Accepted 8/11/2011 (004722)

Department of Foods and Nutrition, School of Food Engineering, State University of Campinas- UNICAMP, PO Box 6121, CEP 13083-862, Campinas, SP, Brazil,

e-mail: fabianelaflor@gmail.com

${ }^{2}$ Pediatric Research Center, Faculty of Medical Sciences, State University of Campinas- UNICAMP, PO Box 6121, CEP 13083-887, Campinas, SP, Brazil

${ }^{*}$ Corresponding author
} 
2004; MARSHALL, 2004). These properties can be summarized as follows: antitumoral action through GSH (glutathione) and lymphocytes stimulation and immunoglobulin synthesis, and production and propagation of antioxygen free-radicals (ROS); protection of DNA through neutralization of toxic and procarcinogenic substances, stabilization of DNA through methylation of specific DNA sites, protection of the gastrointestinal mucosa by stimulation of prostaglandin synthesis $\left(\mathrm{PGE}_{2}, \mathrm{PGI}_{2}\right)$; stimulation and formation of mucus, and inhibition of gastrin, antiviral, and antibacterial activities.

The objective of the present research was to compare the properties of five different Whey Protein Concentrates (WPC) or isolates (WPI) with respect to their capacity to promote body growth and stimulate glutathione (GSH) synthesis by hepatocytes and erythrocytes (in rats). In addition, this study also aimed to stimulate (in vitro) the secretion of cytokines by healthy Human Peripheral Blood Mononuclear Cells (HPBMC), in the absence or presence of the antigen from Bacillus CalmetteGuérin (BCG) vaccine, and inhibit the proliferation of murine melanoma cells.

The ultimate aim of this work was to select one of the products to be used as a food supplement to possibly ameliorate infection and/or inflammation in conditions such as mucositis (in chemotherapy), pediatric cystic fibrosis, and adult Chron's disease.

\section{Materials and methods}

\subsection{Whey protein products}

The whey protein products investigated in this study were denominated S-1 to S-5 samples. S-1, S-2 and, S-3, kindly provided by Hilmar Ingredients, a division of Hilmar Cheese Company, California, USA. S-1 (Hilmar ${ }^{\mathrm{TM}} 8000$ ) is a whey protein concentrate (WPC); S-2 (Hilmar ${ }^{\mathrm{TM}} 8350$ ) a whey protein hydrolysate (WPH); and S-3, a Hilmar experimental product, which is a WPC enriched with TGF- $\beta$, a cell transforming factor, and lactoferrin; S-4 (Alacem $\left.{ }^{\mathrm{TM}}\right)$, a WPC purchased from New Zealand Milk Products (NZMP-São Paulo, BR) and S-5, an experimental product (WPI) produced in Rennes, France.

The starting material for all Hilmar products was cheese whey submitted to microfiltration, ultrafiltration, diafiltration, and dehydration by spray-drying. The S-2 (WPH) sample was obtained by enzymatic hydrolysis of the commercial WPC, the hydrolysate was then concentrated and dehydrated by spraydrying.

S-5, a Whey Protein Isolate (WPI) was obtained after microfiltration to separate casein micelles, following by ultrafiltration, diafiltration, and lyophilization.

\subsection{Basic chemical analysis}

Dry extract, ash, protein, and moisture contents were determined according to the procedures described in the AOAC (ASSOCIATION...,1990); total lipids, by the method of Bligh and Dyer (1959), and lactose according to the method described by Acton (1977).

\subsection{Amino acid determination}

The amino acids in the acid hydrolysates $\left(110^{\circ} \mathrm{C}, 6 \mathrm{~N} \mathrm{HCl}\right.$, 22 hours) were identified on a cation exchange chromatographic column (amino acid analyzer), and post-column quantification was performed by ninhydrin reaction (SPACKMAN; STEIN; MOORE,1958) using a standard amino acid mixture from Pierce (USA).

\subsection{Protein solubility}

Protein solubility in water $(\mathrm{pH} 4.6)$ was determined according to the standard method described by Morr et al. (1985).

\subsection{Biological assays}

The experiments on rats were performed at the Biological Test Laboratory, Department of Food and Nutrition (DEPAN), School of Food Engineering (UNICAMP), Campinas-SP and were approved by the Ethics Committee for Animal Experimentation/Unicamp through protocol number 1065-1.

Forty Specific Pathogen Free (SPF) weanling (21 days) male Wistar rats were used in the biological assays. The rats were provided by the Center for Multidisciplinary Investigations in Biology (CEMIB) of the University of Campinas (UNICAMP). At the beginning of the experiment, the average body weight of the rats was $57.9 \pm 7.3 \mathrm{~g}$. The diets were based on the AIN-93 (REEVES; NIELSEN; FAHEY, 1993) standard diet for laboratory rodents (American Institute of Nutrition), in which 12\% of whey protein product was substituted for the recommended $17 \%$ casein. The $5 \%$ difference in protein concentration was compensated by adding an extra $5 \%$ carbohydrate. The animals received water and diet ad libitum throughout the experiment. The environmental conditions of the laboratory were maintained under controlled temperature at $22 \pm 2{ }^{\circ} \mathrm{C}$ and alternate 12 hours periods of light and darkness.

The experimental protocol for the rat assay is shown in Figure 1. Weight gain, blood glutathione, and liver glutathione were measured after 7 and 21 days of diet administration.

\subsection{Glutathione determination}

Blood erythrocyte and liver glutathione (GSH) levels were determined using the glutathione reductase method described by Griffth (1980).

\subsection{Cultivation of murine melanoma cells}

B16F10 murine melanoma cells were provided by the Ludwig Institute, Lausanne, Switzerland. The cells were grown in $75 \mathrm{~cm}^{3}$ flasks in RPMI-1640 medium (GIBCO) supplemented with $10 \%$ inactive fetal bovine serum (CULTILAB), $2 \mathrm{mM}$ of L-glutamine (SIGMA CHEMICAL COMPANY), $1 \mathrm{mM}$ sodium pyruvate, and the antibiotics streptomycin $0.1 \mathrm{mg} \cdot \mathrm{mL}^{-1}$ and ampicilin $0.1 \mathrm{mg} \cdot \mathrm{mL}^{-1}$ (FONTOURA WYETH AS). Prior to adherence, the cells were cultivated to maintain and multiply the strain to be frozen in the medium (RPMI-1640) with 10\% dimethylsulfoxide (DMSO, SIGMA CHEMICAL COMPANY) and then stored in liquid nitrogen (GERAN, 1972). 


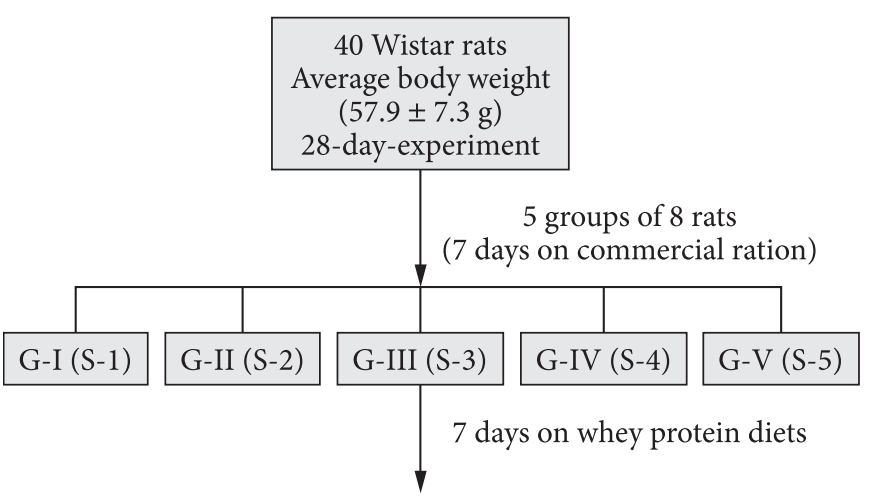

Sacrificed: 4 rats of each treatment 14 days on whey protein diets

Sacrificed: 4 rats of each treatment

Figure 1. General protocol for the rat assay. Letter $\mathrm{G}$ followed by roman numbers (I to $\mathrm{V}$ ) identify the experimental groups, and the letter $\mathrm{S}$ followed by arabic numbers ( 1 to 5 ) identify the experimental samples. S-1: commercial WPC; S-2: commercial WPH; S-3: experimental WPC (TGF- $\beta$ and LF enriched); S-4: commercial WPI; and S-5: experimental WPI. G-I to G-V, rat experimental groups.

Suspensions of B16F10 adherent cells were obtained by treating the cultures with $0.2 \%$ trypsin (VINDELOV; CHRISTENSEN; NISSEN, 1983) for 5 minutes and then deactivating them in $10 \%$ fetal bovine serum. The nonadherent cells were centrifuged twice and then ressuspended in the supplemented RPMI-1640 medium. A Malassez camara was used to count cells. Cell concentration was adjusted to $5 \times 10^{5}$ cells. $\mathrm{mL}^{-1}$ for the RPMI-1640 medium supplemented with $10 \%$ fetal bovine serum and $7 \mathrm{~g}$ of Polimixin-B (SIGMA CHEMICAL COMPANY, ST LOUIS MO-USA). Cell viability was determined through an exclusion test and measurement of cellular permeability using the reagent Trypan Blue. Only nonviable cells are permeable to the reagent and are stained. Viable cells are given by the difference between total and stained cells. Over $95 \%$ of the cells were viable.

\subsection{Cytotoxicity assay - MTT}

The viability of tumoral cell strain after 24 hours of treatment with whey protein, concentrations ranging from 0.1 to $10.0 \mathrm{mg} \cdot \mathrm{mL}^{-1}$, was determined using MTT colorimetric assays (3-(4,5-dimethylthiazol-2-y1)2,5-diphenyl tetrazolium bromide), as described by Mosmann (1983). This method is based on the reduction of the MTT to formazan by living cells. The non-viable cells were identified using tumor cell suspensions incubated in 96-well plates under sterile conditions. Aliquots of $10 \mu \mathrm{L}$ of MTT ( $5 \mathrm{mg} \cdot \mathrm{mL}^{-1}$ ) were added to the suspensions, which were incubated for 3 hours at $37^{\circ} \mathrm{C}$ in an oven containing $5 \%$ of $\mathrm{CO}_{2}$. Next, the culture medium was removed and $100 \mu \mathrm{L}$ of DMSO were added to dissolve the formazan crystal, which remained as a blue precipitate. Absorbances were read using ELISA plate at a wave length of $540 \mathrm{~nm}$ (TITERTEK MULTISKAN).

\subsection{Cytokine modulation evaluation}

Cytokine secretion and modulation (GAINES; ANDERSON; BIBERFED, 1996) in Human Peripheral Blood Mononuclear Cells (HPBMC) were analyzed using cultivated $\left(2 \times 10^{6}\right.$ cells. $\mathrm{mL}^{-1}$ ) in round-bottomed, 96-wells tissue culture plates in the presence or absence of the BCG antigen (BCG Moreau, FIOCRUZ, Rio de Janeiro, Brazil; Bacillus Calmette - Guérin vaccine, $5 \times 10^{5}$ UFC. $\mathrm{mL}^{-1}$, Butantan Institute, SP, Brazil). RPMI - 1640 basic culture medium (Sigma, Saint Louis, Mo, USA) was used.

The protein concentration used throughout the assays was $200 \mu \mathrm{g} . \mathrm{mL}^{-1}$ of culture medium. Eight independent assays were performed for the cytokines (IL-4, IL-10, TNF- $\alpha$ ).

The RPMI-1640 medium was supplemented with $10 \%$ human serum AB-HNS (SIGMA, USA), 1\% glutamine, and $0.1 \%$ gentamicin (SIGMA, USA). Plates containing suspended cells were incubated at $37^{\circ} \mathrm{C}, 5 \% \mathrm{CO}_{2}$, and $95 \%$ air in a humidified atmosphere chamber. After 48 hours of incubation, supernatants were collected and stored at $-80{ }^{\circ} \mathrm{C}$ until assays for cytokine concentration were carried out. Peripheral blood mononuclear cells were collected from eight healthy individuals, and independent assays were performed for the cytokines (IL-4, IL10, TNF- $\alpha$ ). TNF- $\alpha$ (tumor necrosis factor alpha), interleukin-4 (IL-4), and interleukin-10 (IL-10) were determined in the supernatant cultures (duplicate reading) on a two-MAb sandwich ELISA (DUO SET', R\&D SYSTEMS, MINEAPOLIS, MN, USA) in flat-bottomed MultiSorp ELISA plates (NUNC, DENMARK), according to the manufacturers' protocols. Recombinant cytokines were used for the standard curves.

\subsection{Statistical analysis}

Differences in weight gain, blood glutathione, and liver glutathione were tested for statistical significance by using Basic Statistics and Tables software to perform a variance analysis and identify differences between the means in accordance with the Duncan or the Tukey tests at $\mathrm{p}<0.05$ (GOMES, 1982). The statistical analysis for cytokines was performed utilizing SPSS software. Descriptive data were expressed as medians of minimum and maximum values found. The differences between the groups were analyzed using the Wilcoxon test $(\mathrm{p}<0.05)$.

\section{Results}

\subsection{Samples composition and characterization}

Table 1 shows the basic chemical composition of the various whey protein samples studied. The protein content ranged from $76 \%(\mathrm{~S}-1)$ to $92.6 \%$ (S-5). Moisture content varied from $3.4 \%$ (S-5) to $6.7 \%(\mathrm{~S}-3)$; ash from $1.3 \%(\mathrm{~S}-4)$ to $5.6 \%(\mathrm{~S}-2)$; fat from $1.0 \%(\mathrm{~S}-5)$ to $11 \%(\mathrm{~S}-3)$; and lactose from $0.9 \%(\mathrm{~S}-5)$ to $8.5 \%$ (S-3).

Table 2 shows the amino acid profiles of all five whey protein samples. The profiles are typical of the amino acid composition of whey proteins: high in leucine, lysine, sulfur-containing amino acids, tryptophan and threonine, and glutamic and aspartic acids. 
Protein solubility (water at $\mathrm{pH} 4.6$ ) was close to $100 \%$ for S-4 and S-5 and around 90\% for samples 1, 2, and 3.

\subsection{Biological assay}

According to the general protocol, after 7 days, there were no statistical differences in the weight gain among the five groups of rats (GI to GV) fed commercial ration (Figure 1), and the average was $37.1 \pm 4.6 \mathrm{~g}$. The growth rate of the rats on experimental diets for 21 days is shown in Figure 2. Once again, there were no differences in the rates of growth among the five groups; all groups presented continuous growth curves. Average dietary consumption and average weight gain during 21 days of experiment were $343.8 \pm 10.0 \mathrm{~g}$ and $107.5 \pm 3.2 \mathrm{~g}$, respectively.

Total glutathione (GSH) concentrations in the blood erythrocytes and liver tissues were determined after 7 and 21 days on special whey protein diets. Figure 3 presents the results for blood erythrocytes $\left(\mathrm{mmol} . \mathrm{L}^{-1}\right)$. Comparing the results of the erythrocyte glutathione content obtained for all five dietary

Table 1. Basic chemical composition of whey protein samples.

\begin{tabular}{lrrrrr}
\hline \multicolumn{1}{c}{$\begin{array}{c}\text { Components } \\
\text { (\%) }\end{array}$} & S-1 & S-2 & S-3 & S-4 & S-5 \\
\cline { 2 - 6 } Protein (wet basis) & 76.0 & 73.8 & 70.6 & 89.3 & 92.6 \\
Moisture & 6.2 & 5.1 & 6.7 & 5.6 & 3.4 \\
Ash & 3.6 & 5.6 & 2.8 & 1.3 & 2.1 \\
Fat & 6.7 & 6.8 & 11.0 & 1.8 & 1.0 \\
Lactose & 5.7 & 5.5 & 8.5 & 2.0 & 0.9 \\
Protein (dry basis) & 81.0 & 77.8 & 75.7 & 94.6 & 95.8 \\
\hline
\end{tabular}

S-1: commercial WPC; S-2: commercial WPH; S-3: experimental WPC (TGF- $\beta$ and LF enriched); S-4: commercial WPI; S-5: experimental WPI.

Table 2. Complete amino acid profiles of five whey protein products.

\begin{tabular}{|c|c|c|c|c|c|}
\hline \multirow{2}{*}{$\begin{array}{c}\text { Amino acid } \\
(\% \text { of total AA })\end{array}$} & \multicolumn{5}{|c|}{ Samples } \\
\hline & S-1 & $\mathrm{S}-2$ & S-3 & S-4 & S-5 \\
\hline \multicolumn{6}{|l|}{ Essential } \\
\hline Histidine & 1.6 & 1.5 & 1.9 & 2.0 & 1.7 \\
\hline Isoleucine & 6.1 & 6.0 & 5.8 & 5.0 & 6.0 \\
\hline Leucine & 10.3 & 10.2 & 10.3 & 12.8 & 12.4 \\
\hline Lysine & 10.1 & 10.8 & 8.6 & 10.2 & 10.4 \\
\hline Methionine & 2.1 & 2.0 & 3.1 & 2.4 & 3.0 \\
\hline Cystine/CySH & 2.8 & 1.7 & 2.3 & 2.5 & 2.9 \\
\hline Phenylalanine & 3.0 & 3.1 & 3.5 & 3.4 & 4.1 \\
\hline Tyrosine & 3.2 & 2.7 & 3.2 & 3.3 & 3.9 \\
\hline Tryptophan & 1.7 & 1.3 & $\mathrm{ND}$ & 2.0 & 2.5 \\
\hline Valine & 5.7 & 5.6 & 5.3 & 4.8 & 5.8 \\
\hline Threonine & 6.5 & 7.4 & 6.3 & 4.7 & 5.3 \\
\hline \multicolumn{6}{|l|}{ Non-essential } \\
\hline Alanine & 4.9 & 5.3 & 5.0 & 5.3 & 4.8 \\
\hline Arginine & 2.4 & 2.7 & 3.3 & 2.4 & 2.9 \\
\hline Aspartic acid & 10.4 & 11.0 & 10.9 & 11.5 & 11.5 \\
\hline Glutamic acid & 16.9 & 15.7 & 16.9 & 17.6 & 18.1 \\
\hline Glycine & 1.7 & 1.9 & 2.1 & 1.6 & 2.0 \\
\hline Proline & 5.7 & 5.9 & 5.9 & 4.1 & 5.0 \\
\hline Serine & 5.0 & 5.2 & 5.5 & 3.8 & 4.8 \\
\hline
\end{tabular}

S-1: commercial WPC; S-2: commercial WPH; S-3: experimental WPC (TGF- $\beta$ and LF enriched); S-4: commercial WPI; S-5: experimental WPI. ND, not determined. Results are average values of duplicate analysis for each sample. treatments at day 7 (gray columns), samples S-1, S-3, and S-4 were higher $(\mathrm{p}<0.05)$ than samples $\mathrm{S}-2$ and $\mathrm{S}-5$. However, at day 21 , only the group of animals treated with sample S-5 was lower than the others $(\mathrm{p}<0.05)$. On the other hand, comparing the results for the individual dietary groups at day 7 and day 21, the samples S-2, S-3, and S-5 were statistically higher at day 21, while the samples S-1 and S-4 were not different at days 7 and $21(\mathrm{p}>0.05)$

As for liver GSH (Figure 4), no differences were found at day 7 or 21 comparing all five treatments. However, comparing each treatment separately, the glutathione concentration of S-1, S-2, and S-3 treatments was lower at day 7 than at day $21(\mathrm{p}<0.05)$.

\subsection{Cytotoxicity on B16F10 murine melanoma cells}

Table 3 shows the percentage of B16F10 murine melanoma cell death for the whey protein samples (S-2 to S-5) evaluated in vitro using two different concentrations $\left(2.5\right.$ and $5 \mathrm{mg} \cdot \mathrm{mL}^{-1}$ of culture medium). The cytotoxicity found on melanoma B16F10 cells was the highest (70\%) in the S-2 medium at $5 \mathrm{mg} \cdot \mathrm{mL}^{-1}$, followed by S-3 and S- 4 with 48 and $42 \%$ toxicity, respectively. The $\mathrm{IC}_{50}$ (protein concentration to inhibit $50 \%$ of cells replication) was obtained from in vitro testing of S-2 and S-3 samples on B16F10

Table 3. Percentage of cytotoxicity (cell death)* of B16F10 murine melanoma cells caused by the whey protein products tested.

\begin{tabular}{ccc}
\hline $\begin{array}{c}\text { Samples } \\
(\mathrm{S})\end{array}$ & $\begin{array}{c}\text { Concentration of sample in the media } \\
\left(\mathrm{mg}_{\mathrm{mL}} \mathrm{m}^{-1}\right)\end{array}$ & $\begin{array}{c}\text { Citotoxicity } \\
\text { (\% cell death) }\end{array}$ \\
\hline S-2 & 2.5 & 0.6 \\
& 5.0 & 70.4 \\
S-3 & 2.5 & 42.3 \\
& 5.0 & 47.8 \\
S-4 & 2.5 & 21.4 \\
& 5.0 & 42.2 \\
S-5 & 2.5 & 5.6 \\
& 5.0 & 7.5 \\
\hline
\end{tabular}

${ }^{*}$ Average in duplicate. Sample 1 was not submitted to this test; S-2: commercial WPH; S-3: experimental WPC (TGF- $\beta$ and LF enriched); S-4: commercial WPI; S-5: experimental WPI.

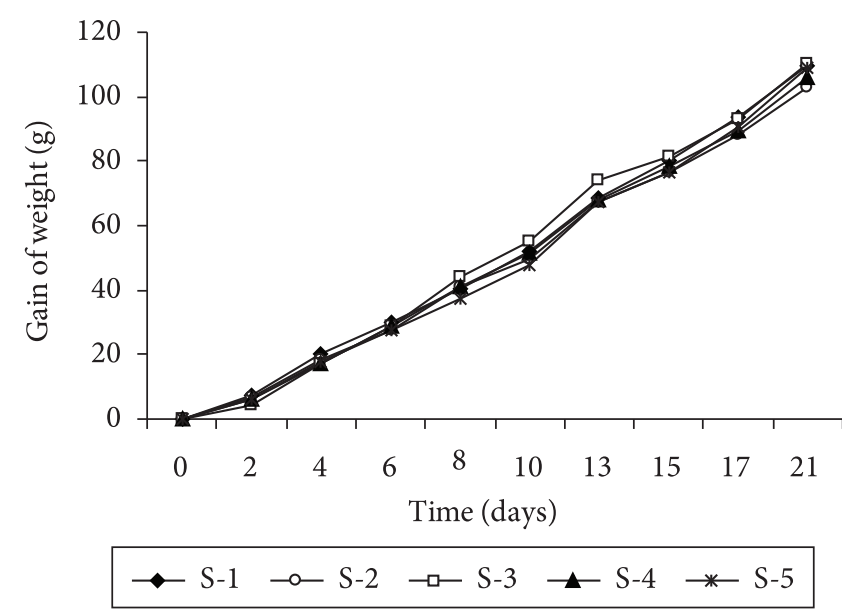

Figure 2. Growth rate of 5 groups of Wistar rats treated with different whey protein samples: S-1: commercial WPC; S-2: commercial WPH; S-3: experimental WPC (TGF- $\beta$ and LF enriched); S-4: commercial WPI; and S-5: experimental WPI. 


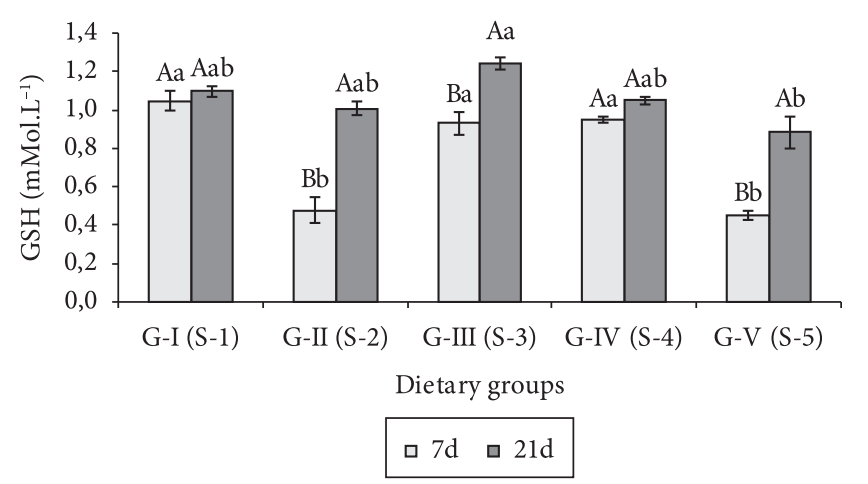

Figure 3. Erythrocytes glutathione concentration $\left(\mathrm{mmol} . \mathrm{L}^{-1}\right)$ of blood after 7 and 21 days on the special protein diets. Lowercase letters (a, b) compare all dietary treatments at $7 \mathrm{~d}$ or $21 \mathrm{~d}$. Capital letters $(\mathrm{A}, \mathrm{B})$ compare each dietary treatment at $7 \mathrm{~d}$ with 21 days of feeding the diets. S-1, commercial WPC; S-2, commercial WPH; S-3, experimental WPC (TGF- $\beta$ and LF enriched); S-4, commercial WPI; and S-5, experimental WPI. G-I to G-V, rat experimental groups.

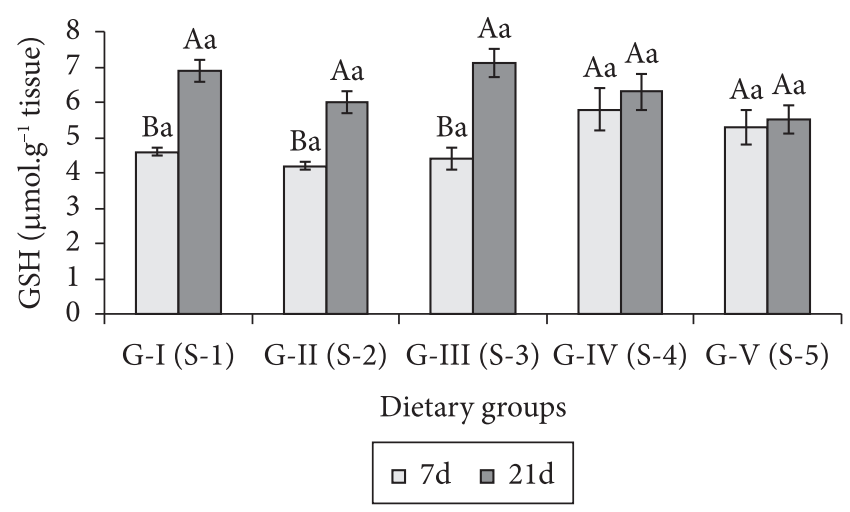

Figure 4. Effect of feeding different whey protein diets for $7 \mathrm{~d}$ and 21d on rat liver glutathione (GSH). Lowercase letters (a) compare all dietary treatments at 7 or $21 \mathrm{~d}$. Capital letters (A, B) compare each dietary treatment at $7 \mathrm{~d}$ with $21 \mathrm{~d}$ of feeding the diets. S-1: commercial WPC; S-2: commercial WPH; S-3: experimental WPC (TGF- $\beta$ and LF enriched); S-4: commercial WPI; and S-5: experimental WPI. G-I to $\mathrm{G}-\mathrm{V}$, rat experimental groups.

melanoma cells. The $\mathrm{IC}_{50}$ for S-2 was $3.66 \mathrm{mg} \cdot \mathrm{mL}^{-1}$, and that for $\mathrm{S}-3$ was $2.68 \mathrm{mg} \cdot \mathrm{mL}^{-1}$. With regard to $\mathrm{IC}_{50}$ and $\mathrm{B} 16 \mathrm{~F} 10$, melanoma tumor cells, product 3 showed higher bioactivity at lower protein concentration (2.5 mg. $\mathrm{mL}^{-1}$ of culture medium). The quadratic equations below allowed the calculation of the $\mathrm{IC}_{50}\left(\mathrm{mg} \cdot \mathrm{mL}^{-1}\right)$ for samples S-2 (Equation 1) and S-3 (Equation 2).

$$
\begin{aligned}
& y=3.1726 x^{2}+1.1013 x+3.5006\left(R^{2}=0.9947\right) \\
& y=7.929 x^{2}-4.3915 x+4.8594\left(R^{2}=0.9787\right)
\end{aligned}
$$

In Equations 1 and 2, y stands for 50\% inhibition of cell replication $\left(\mathrm{IC}_{50}\right), \times$ for protein concentration in the culture medium ( $\mathrm{mg} \cdot \mathrm{mL}^{-1}$ ), and $\mathrm{R}^{2}$ for the coefficient of determination.

\subsection{Cytokine secretion by human peripheral mononuclear cells (HPBMC)}

The modulation of cytokine secretion in Human Peripheral Blood Mononuclear Cells (HPBMC) by the various bovine whey protein products was studied in culture medium with or without the presence of an antigen (BCG) and with $200 \mu \mathrm{g} \cdot \mathrm{mL}^{-1}$ or without the presence of whey proteins (controls). The cytokines studied were interleukin-10 (IL-10), the tumor necrosis factor alpha (TNF- $\alpha$ ), and interleukin-4 (IL-4).

Table 4 shows the effect of the whey protein samples on cytokine secretion by HPBMC in the absence of BCG.

With respect to IL-10 secretion, a comparison between the stimulatory capacity of control and culture medium the capacity of the culture medium containing whey protein samples $\left(200 \mu \mathrm{g} \cdot \mathrm{mL}^{-1}\right)$ indicates that samples 1,2 , and 3 were significantly higher compared to S-4 and S-5, and that sample 3 had the highest activity. With regard to TNF- $\alpha$, only S-3 and S-1 significantly differed from the control. None of the whey proteins differed from the control medium with respect to the secretion of interleukin-4 (IL-4) in the absence of BCG.

In the presence of $B C G$, all whey protein samples stimulated the secretion of IL-10 (Table 5) compared to the control medium containing only BCG. However, BCG repressed the stimulation of TNF- $\alpha$ and IL- 4 in all samples studied.

\section{Discussion}

The gross chemical composition of the whey protein products studied varied depending on the methods of preparation and the classification as WPC (Whey Protein Concentrate) or WPI (Whey Protein Isolate). The principal variation observed was in protein content (dry basis), which ranged from $76-81 \%$ for samples S-1, S-2, and S-3 but was approximately $95 \%$ for S-4 and S-5.

The lower solubility of sample S-2 was not expected since a protein hydrolysate the solubility should be higher than for the non-hydrolyzed WPC. This may be attributable to Maillard type reactions or some other type of molecular interaction during hydrolysis and/or drying since the color of this sample was darker than that of the others (SGARBIERI; FARFAN; TANAKA, 1973).

The amino acid composition of the whey proteins analyzed was similar and characteristic of such products.

The total growth and the growth rate curves produced by the whey protein samples investigated were also similar.

Tissue glutathione content was measured in the blood (erythrocytes) and in liver after 7 and 21 days of protein dietary treatment and showed some significant variations $(\mathrm{p}<0.05)$ between these two periods of treatments.

Figure 3 shows the effect of the various protein diets on total glutathione concentration in the rat erythrocytes. After 7 days of feeding, higher GSH levels were found for S-1, S-3, and S-4 protein diets $(\mathrm{p}<0.05)$ than those of S-2 and S-5. However, no difference was observed among the first three samples or between the last two.

There is no apparent reason why S-5 should have shown a lower erythrocyte GSH after 7 days of feeding. It has been repeatedly suggested (BOUNOUS; KONGSHAVN; GOLD, 1988; BOUNOUS; GOLD, 1991) that the extent of tissue 
Ziegler et al.

Table 4. Effect of whey products on cytokine secretion in supernatant culture of Human Peripheral Blood Mononuclear Cells (HPBMC).

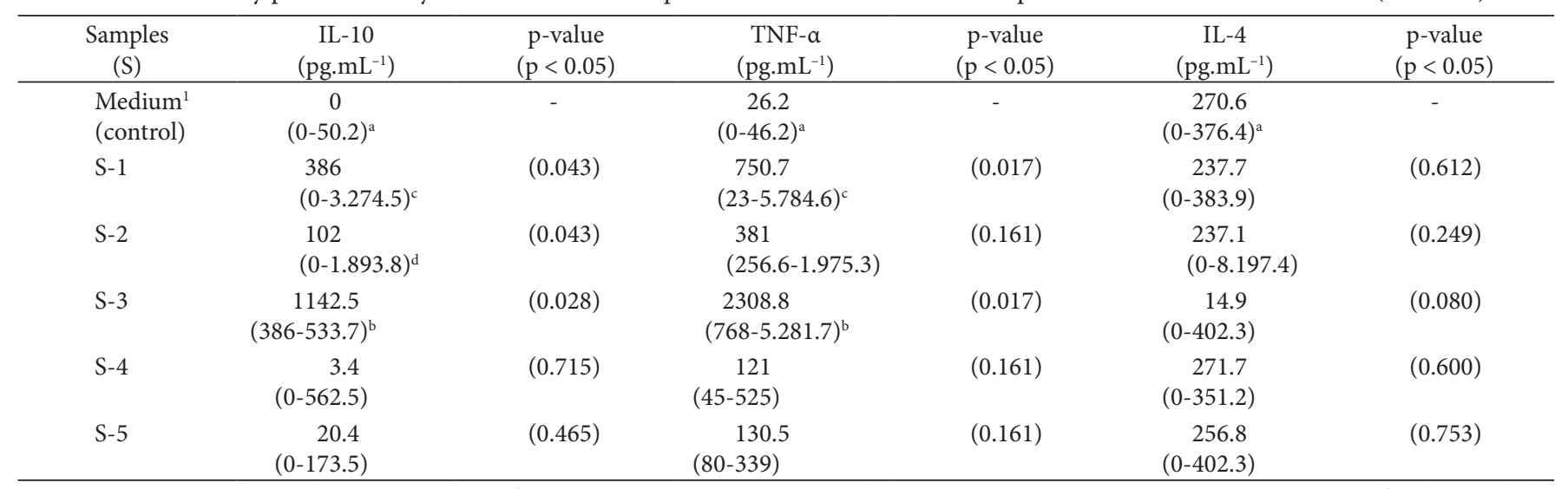

${ }^{1}$ Medium RPMI-1640: Culture medium at concentration of $5 \times 10^{5}$ CFU/monocytes. S-1: commercial WPC; S-2: commercial WPH; S-3: experimental WPC (TGF- $\beta$ and LF enriched); S-4: commercial WPI; S-5: experimental WPI. NS, not significant. Data expressed as median of (minimum and maximum) values.

Table 5. Effect of the five whey protein products on cytokine secretion in supernatant culture of human peripheral blood mononuclear cells (HPBMC) in the presence of the BCG vaccine.

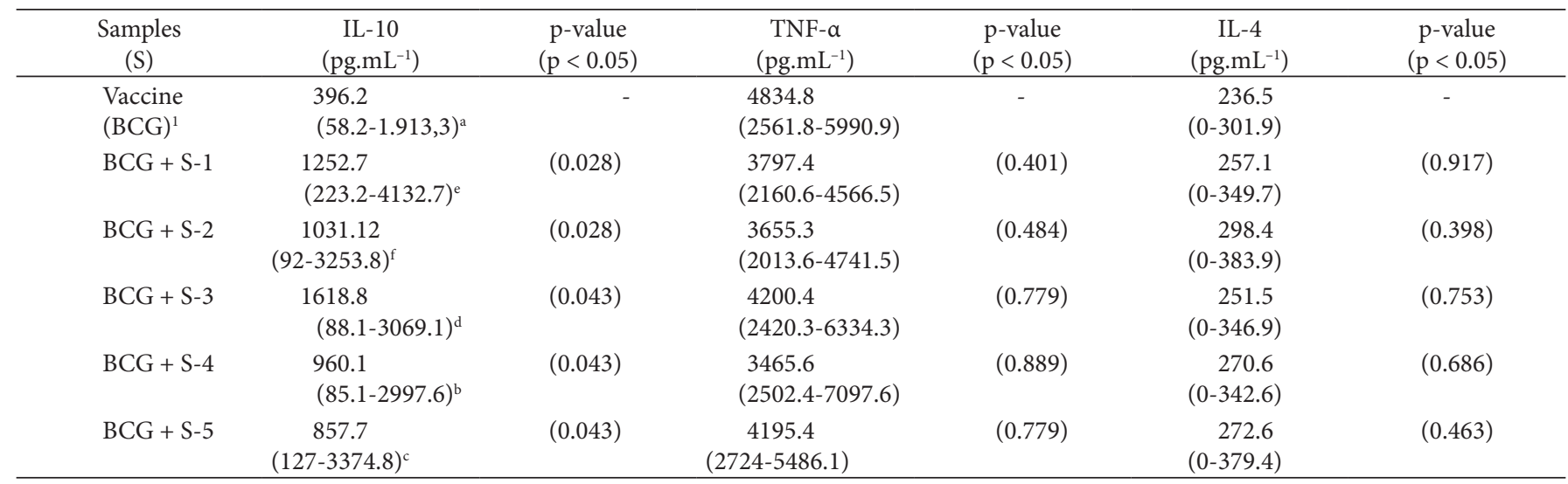

${ }^{1}$ BCG: Bacillus Calmette-Guérin (Instituto Butantan, São Paulo, SP). S-1: commercial WPC; S-2: commercial WPH; S-3: experimental WPC (TGF- $\beta$ and LF enriched); S-4: commercial WPI; S-5: experimental WPI. Data expressed as median of (minimum and maximum) values. NS, not significant.

stimulation of GSH synthesis, on feeding rodents with whey proteins, depends on the concentration of total S-amino acids in the protein samples, mainly cystine/cysteine.

Our data (Table 2) shows the lowest concentration of S-amino acids in S-2 sample, which seems to justify the lower GSH content in the group of rats that received this product. In contrast, no apparent reason explains why S-5 with higher S-amino acids content showed lower erythrocyte GSH at day 7. This result seems to contradict the hypothesis that tissue GSH concentration depends only on S-amino acids in whey proteins.

The data presented suggest that other factors are also capable of influencing GSH concentration in the erythrocytes. Factors such as production technology and post-production handling of samples may be of importance influencing not only composition but also amino acid bioavailability.

Higher liver GSH ( $\mu$ moles.g ${ }^{-1}$ fresh tissue) for whey proteins than for other dietary proteins have been reported in previous studies (PACHECO; SGARBIERI, 2005; DIAS et al, 2006), including one study concerning a pilot WPC produced experimentally in Tecnolat, ITAL (ZINSLY et al., 2001). In these experiments, the rats and/or mice were stimulated with an injection of $10^{6}$ Sheep Red Blood Cells (SRBC) 7 days prior to sacrifice, procedure not done in the present experiment. Furthermore, a different analytical method using a colorimetric assay to determine GSH (SAVILLE, 1958) was used in previous studies, in which the maximum liver GSH concentration was detected at approximately 5 to 7 days post-immunization. A strong correlation has been demonstrated between GSH concentration in the liver and increased immunoglobulin in the mice spleen (BOUNOUS; KONGSHAVN; GOLD, 1988; DIAS et al., 2006).

In the present study, there was no immunization prior to GSH determination at either 7 or 21 days of protein diet feeding. No statistical difference was found in the rat liver for all five protein dietary groups at both 7 and 21 days of feeding. However, increased GSH contents were detected at day 21 for the rat groups fed the protein samples S-1, S-2, and S-3 ( $<<0.05)$, which differed from the groups that received S-4 and S-5 samples and showed identical liver GSH concentration after 7 and 21 days.

Comparing the results of previous published studies (BOUNOUS; KONGSHAVN; GOLD,1988; DIAS et al., 2006) with the data presented in this paper, we were tempted to suggest that immunization speeds up GSH synthesis in the 
rat liver making it to peak at around 7 days after the antigen challenge. On the other hand, in the absence of immunization, the liver GSH peak seems to occur at a later period of feeding the protein diet.

The highest level of toxicity (70\%) for murine melanoma cells was produced by the medium containing S-2, followed by that containing S-3 (48\%), both under product concentration of $5 \mathrm{mg} \cdot \mathrm{mL}^{-1}$ of culture medium. At the the lowest concentration (2.5 mg.mL $\mathrm{mL}^{-1}$ ) of medium, S-3 sample presented the highest cytotoxicity $(42.3 \%)$. In terms of $\mathrm{IC}_{50}, \mathrm{~S}-3$ sample exhibited higher activity, 2.68 against $3.66 \mathrm{mg} \cdot \mathrm{mL}^{-1}$ for $\mathrm{S}-2$.

Assays for IL-10 and TNF- $\alpha$ in the absence of antigen (BCG) in the culture medium showed S-1 and S-3 to be distinctly higher for stimulating the secretion of these cytokines, especially considering that the degree of stimulation of S-4 and S- 5 samples was zero. None of the whey protein samples tested under the assay conditions stimulated the IL-4.

In the presence of BCG antigen none of the five whey protein preparations stimulated the secretion of either TNF- $\alpha$ or IL-4. In contrast, all five preparations stimulated the secretion of IL-10 ( $\mathrm{p}<0.05)$, and S-1 and S-2 were the most effective. BCG antigen was chosen because it has been used as a vaccine against peripheral blood mononucleosis, and previous results have shown that it is an effective stimulator of cytokine production in Human Peripheral Blood Mononuclear Cells (HPBMC) cultures.

In the case of samples S-1 and S-3, the high erythrocytes concentrations of GSH after 7 days of feeding were associated with high rates of secretion of IL-10 and TNF-a.

The precise significance of these observations is difficult to explain due to the fact that GSH concentrations were determined in rat assays, whereas the IL-10 and TNF- $a$ levels were determined in culture supernatants in Human Peripheral Blood Mononuclear Cell (HPBMC). Nevertheless, it appears to be significant that IL-10 (a regulatory interleukin), TNF- a (a multifunctional immune modulator), and GSH were stimulated both in vitro and in vivo in the absence of the antigen.

Cross and Gill (1999) have shown that, in vitro, whey proteins suppresses $\mathrm{T}$ and $\mathrm{B}$ lymphocytes proliferative responses to mitogens and the cytokine (IFN- $\gamma$ and IL-4) secretion. Furthermore, in mice, whey protein have been shown to enhance splenic immune response to sheep red blood cells (BOUNOUS; KONGSHAVN; GOLD,1988; BOUNOUS; BATIST; GOLD, 1989; BOUNOUS; GOLD, 1991).

In HIV-infected children, increased GSH has been found following whey protein supplementation (BARUCHEL, 1998; MORENO et al., 2005). It has also been demonstrated (CAYOTA et al., 1996), in vitro, that the ability of HIVinfected individuals to proliferate $\mathrm{TCD}_{4}$ is correlated with GSH restoration.

The immune modulation mechanisms of whey proteins seem to be related to their amino acid profiles since such proteins contain large amounts of cysteine, glutamate, and glutamylcysteinyl peptides, all of which contribute to GSH synthesis
(GRIFFTH, 1980; BOUNOUS; GOLD, 1991; BARUCHEL; VIAUX, 1996; SGARBIERI, 2004; MARSHALL, 2004).

In addition to its antioxidant action, GSH is also involved in many biological processes (SGARBIERI, 2004; MARSHALL, 2004), promotes cytotoxic activity, and plays an important role in the proliferation of T-cells and synthesis of IL-8 (TREITINGER et al., 2004). Antioxidants and glutathione precursors have been shown to down regulate pro-inflammatory cytokine production (HADDAD et al., 2001).

Cytokines can have either beneficial or detrimental effects, depending on the metabolic context considered and the amounts produced. Although cytokines are essentially beneficial in cases of infections, they may be detrimental in cancer, chronic inflammatory diseases, or in individuals infected with HIV (CROSS; GILL, 1999).

Type $1 \mathrm{~T}$-helper $\left(\mathrm{Th}_{1}\right)$ cells produce interferon-gamma (IFN- $\gamma)$, IL-2 and TNF- $\alpha$, whereas type $2\left(\mathrm{Th}_{2}\right)$ cells produce IL4, IL-6, and IL-10. The Th cytokines (IFN- $\gamma$ and IL-2) increase cellular immunity, whereas the Th 2 cytokines (IL-4, IL-5, IL-6 and IL-10) increase humoral immunity (ABBAS; LICHTMAN; PILLAI, 2008).

The balance of the two types of cytokine populations is important for the maintenance of immune homeostasis in the host. Once the balance is lost, various immunological diseases such as allergies and infections may occur (GRIMBLE, 1998; MATSUZAKI; CHIN, 2000).

According to various authors (GRIMBLE, 2001; GRIMBLE et al., 2002; MATSUZAKI; CHIN, 2000), there is an inverse relationship between inflammation and T-cell function. Inflammation initiates with the secretion of pro-inflammatory cytokines IL-1, IL-6, and TNF- $\alpha$, which induce the production of oxidants (free-radicals) causing pathogen death, damage to tissues, and release of nutrients (glucose, glutamine, S-amino acids), which serve to nourish the immune cells ( $\mathrm{T}$ and $\mathrm{B}$ ) and as substrates for the synthesis of GSH.

In a controlled situation, expression of IL-10 by $\mathrm{Th}_{2}$ cells should act in a feedback inhibition, which also involves production of IL-1 receptor antagonist (IL-1 ra) resulting in the down regulation of nuclear factor-kapa B (NF-kB) by enhancement of antioxidant defenses. In these antiinflammatory and antioxidant processes, both IL-10 and GSH play an important role.

Failure to terminate the inflammatory response, once its primary purpose of defeating pathogens has been achieved, may result in immune suppression and hyper inflammation, oxidant damage (insufficient antioxidant supply), and excessive loss of body tissue components.

Nutritional support in the form of proteins, individual amino acids and antioxidants, can increase the availability of substrates for synthesizing peptides and proteins for regulating inflammatory processes (MATSUZAKI; CHIN, 2000; GRIMBLE et al., 2002).

According to our test results for: a) gross chemical composition and amino acid profiles of the concentrates and isolates tested; b) stimulation of GSH synthesis; c) cytotoxicity 
of the products on B16F10 murine melanoma cells; and d) cytokines (IL-4, IL-10 and TNF- $\alpha$ ) secretion by HPBMC; it is clear that S-1 and S-3 were the most bioactive materials. S-3 sample was the strongest secretor of TNF- $\alpha$ and IL-10, while the five samples were similar with respect to all other characteristics.

S-3 sample is a WPC enriched approximately ten-fold in TGF- $\beta$ and lactoferrin. The TGF- $\beta$, a dimmer molecule with 112 amino acids residues and molecular mass of approximately $25 \mathrm{kD}$, inhibits the proliferation of a variety of normal epithelial cell types and hematopoietic stem cells, and therefore it is useful in preventing epithelial cell damage during chemotherapy (IWATA et al.; 1999; SONIS et al.; 1994).

Recent investigations revealed (BECKER; FANTINI; NEURATH, 2006) implications of TGF- $\beta$ in the suppression of T-cells mediated autoimmune inflammation, anti-tumor immunity, and in modification of Th cells $\left(\mathrm{Th}_{1}\right.$ and $\left.\mathrm{Th}_{2}\right)$ into $\mathrm{T}$ regulatory cells $\left(\mathrm{Th}_{\mathrm{reg}}\right)$, which seem to be important in the down regulation of inflammatory processes.

The epithelial anti-proliferation and anti-inflammatory effects on T-cells of TGF- $\beta$, in combination with the immunomodulatory, antioxidant, and antibacterial and antiviral properties of lactoferrin, reinforced our hypothesis that the product represented by S-3 should be particularly helpful as a food supplement in combating infectious and inflammatory processes associated with pathological conditions such as mucositis, a side effect of chemotherapy, cystic fibrosis, and Chron's disease.

\section{Conclusion}

In the present research, S-3 (a WPC enriched with TGF- $\beta$ and lactoferrin) was associated to high in vitro $\mathrm{IC}_{50}$ against melanoma cells, and to a strong stimulation of TNF- $\alpha$ and interleukin-10 secretion by human peripheral mononuclear cells in the absence of stimulating antigen. Among the whey protein samples assayed, S-3 was therefore considered potentially adequate to be used as a dietary supplement for attenuating primary infectious and inflammatory processes associated with different pathologies.

\section{Acknowledgements}

The authors acknowledge the financial support given by FAPESP (Fundação de Amparo à Pesquisa do Estado de São Paulo) and CIPED (Pediatrics Investigation Center of the University of Campinas), and the technical support provided by the Butantan Institute, São Paulo.

\section{References}

ABBAS, A. K.; LICHTMAN, A. H.; PILLAI, S. Imunologia Celular e Molecular. 6. ed. Rio de Janeiro: Elsevier, 2008.

ACTON, G. H. The determination of lactose in cheese. Australian Journal of Dairy Technology, v. 9, p. 111-114, 1977.

ASSOCIATION OF OFFICIAL ANALYTICAL CHEMISTS AOAC. Official Methods of Analysis. 15. ed. Washington: AOAC, 1990. $1141 \mathrm{p}$.
BARUCHEL, S. et al. Nutracentical modulation of glutathione with a humanized native milk serum protein isolate, Immunocal ${ }^{\mathrm{TM}}$; applications in AIDS and cancer. In: MONTAGNIER, L.; OLIVIER, R.; PASQUIER, C. Oxidative stress in Cancer, AIDS and Neurodegenerative Diseases. New York: Marcel Dekker, 1998. p. 447-462.

BARUCHEL, S.; VIAUX, G. In vitro selective modulation of cellular glutathione by a humanized native milk protein isolate in mammal cells and rat mammary carcinoma model. Anticancer Research, v.15, p. 1095-1100, 1996.

BECKER, C.; FANTINI, M. C.; NEURATH, M. TGF-beta as a T cell regulator in colitis and colon cance. Cytokine and Growth Factor Reviews, v. 17, n.1, p. 97-106, 2006. http://dx.doi.org/10.1016/j. cytogfr.2005.09.004

BEZAULT, S. et al. Human lactoferrin inhibits growth of solid tumors and developmental metastasis in mice. Cancer Research, v. 54, n. 9, p. 2310-2312, 1994.

BLIGH, E. G.; DYER, W. J. A rapid method of total lipid extraction and purification. Canadian Journal of Biochemistry Physiology, v. 37, n. 8, p. 911-917, 1959. http://dx.doi.org/10.1139/o59-099

BOUNOUS, G. et al. Whey proteins as a food supplement in HIVsoropositive individuals. Clinical and Investigative Medicine, v. 16, n. 3, p. 204-209, 1993.

BOUNOUS, G.; GOLD, P. The biological activity of undenatured dietary whey proteins: role of glutathione. Clinical and Investigative Medicine, v. 14, n. 4, p. 296-309, 1991.

BOUNOUS, G.; BATIST, G.; GOLD, P. Immunoenhancing property of dietary whey protein in mice: role of glutathione. Clinical and Investigative Medicine, v. 12, n. 3, p. 154-161, 1989.

BOUnOUS, G.; KONGSHAVN, P. A. L.; GOLD, P. The immunoenhancing property of dietary whey protein concentrate. Clinical and Investigative Medicine, v. 11, n. 4, p. 271-278, 1988.

CAYOTA, A. et al. In vitro antioxidant treatment recovers proliferative responses of anergic $\mathrm{CD}_{4}$ lymphocytes from human immunodeficiencyinfected individuals. Blood, v. 87, n. 11, p. 4646-4753, 1996.

CHMIEL, J. F. Anti-tumor effects of dietary whey protein and its value for head and neck cancer patients. International Dairy Federation, v. 4, p. 310-314, 1997.

CROSS, M.; GILL, H. S. Modulation of immune function by a modified whey protein concentrate. Immunology and Cell Biology, v. 77, n. 4, p. 345-350, 1999. PMid:10457202. http://dx.doi.org/10.1046/ j.1440-1711.1999.00834.x

DIAS, N. F. G. P. et al. Dietary protein, immune function and colon carcinogenesis in mouse. Lait, v. 86, n. 3, p. 11-14, 2006.

FISCHER, W. Human -lactalbumin made lethal to tumor cells, kills human glioblastoma cells in brain xenografts by an apoptosis like mechanism. Cancer Research, v. 64, n. 6, p. 2105-2112, 2004. PMid:15026350. http://dx.doi.org/10.1158/0008-5472.CAN-032661

GAINES, H.; ANDERSSON, L.; BIBERFED, G. A new method for measuring lymphoproliferation at the single-cell level in whole blood cultures by flow cytometry. Journal of Immunological Methods, v. 195 , n. $1-2$, p. $63-72$, 1996. http://dx.doi.org/10.1016/00221759(96)00085-3

GERAN, R. I. Protocols for screening chemical agents and natural products against animal tumor and other biological systems. 3 . ed. Bethesda: National Cancer Institute, 1972.

GOMES, F. P. Curso de Estatística Experimental. 10. ed. São Paulo: Nobel, 1982. 
GRIFFTH, O. W. Determination of glutathione and glutathione disulfide using glutathione reductase and 2-vinylpyridine. Analytical Biochemistry, v. 106, n. 1, p. 207-212, 1980. http:// dx.doi.org/10.1016/0003-2697(80)90139-6

GRIMBLE, R. F. Nutritional modulation of immune function. Proceedings of Nutrition Society, v. 60, n. 3, p. 389-397, 2001. http://dx.doi.org/10.1079/PNS2001102

GRIMBLE, R. F. et al. The ability of fish oil to suppress TNF- $\alpha$ production by peripheral blood mononuclear cells, in healthy men, is associated with polymorphisms in genes that influences TNF- $\alpha$ production. American Journal of Clinical Nutrition, v. 76, n. 2, p. 454-459, 2002.

GRIMBLE, R. F. Nutritional modulation of cytokine biology. Nutrition, v.14, n. 7-8, p. 634-640, 1998.

GUSTAFSSON, L. et al. Treatment of skin papillomas with topical a-lactalbumin-oleic acid. New England Journal of Medicine, v. 350, n. 26, p. 2663-2672, 2004. PMid:15215482. http://dx.doi. org/10.1056/NEJMoa032454

HADDAD, J. J. E. et al. Thiol regulation of pro-inflamatory cytokines reveals a novel immunopharmacological potential of GSH in the alveolar epithelium. Journal of Pharmacology and Experimental Therapeutics, v. 296, n. 3, p. 996-1005, 2001.

HÄKANSON, A. et al. Apoptosis induced by a human milk protein. Proceedings of National Academy of Science, v. 92, n. 17, p. 8064-8068, 1995. http://dx.doi.org/10.1073/pnas.92.17.8064

IKEDA, M. et al. Lactoferrin markedly inhibits hepatitis C virus infection in cultured human hepatocytes. Biochemical and Biophysical Research Communications, v. 245, n. 2, p. 549-553, 1998. PMid:9571193. http://dx.doi.org/10.1006/ bbrc. 1998.8481

IWATA, K. K. et al. Tissue-derived tumor growth inhibitors, methods of preparation on uses thereof. US n. 5.871.724, 16 fev. 1999.

JACOBUCCI, H. B. et al. Impact of dietary protein on the rat growth, blood serum lipids and protein, and liver cholesterol. Nutrition Research, v. 21, n. 6, p. 905-915, 2001. http://dx.doi.org/10.1016/ S0271-5317(01)00297-4

KENNEDY, R. S. et al. The use of a whey protein concentrate in the treatment of patients with metastatic carcinoma: phase I-II clinical study. Anticancer Research, v. 15, n. 6B, p. 2643-2650, 1995.

KENT, K. D.; HARPER, W. J.; BOMSER, J. A. Effect of whey protein isolate in intracellular glutathione and oxidant-induced cell death in human prostate epithelial cell. Toxicology in Vitro, v. 17, n. 1, p. 27-33, 2003. http://dx.doi.org/10.1016/S0887-2333(02)00119-4

LAURSEN, I.; BRIAND, P.; LYEKESFELDT, A. E. Serum albumin as a modulator on growth of the human breast cancer cell line, MCF-7. Anticancer Research, v. 10, n. 2A, p. 343-352, 1990.

MARSHALL, K. Therapeutic applications of whey protein. Alternative Medicine Review, v. 9, n. 2, p. 136-155, 2004.

MATSUZAKI, T.; CHIN, J. Modulating immune responses with probiotic bacteria. Immunology Cell Biology, v. 78, n. 1, p. 78: 67-73, 2000.

McINTOSH, G. H.; LE LEU, R. K. The influence of dietary proteins on colon cancer risk. Nutrition Research, v. 21, n. 7, p. 1053-1066, 2001. http://dx.doi.org/10.1016/S0271-5317(01)00306-2

McINTOSH, G. H. et al. Dairy proteins protect against dimethylhydrazine-induced intestinal cancers in rats. Journal of Nutrition, v. 125, n. 4, p. 809-816, 1995.

MEZZAROBA, L. F. H. et al. Antiulcerative properties of bovine a-lactalbumin. International Dairy Journal, v. 16, n. 9, p. 1005-1012, 2006. http://dx.doi.org/10.1016/j.idairyj.2005.10.027

MORENO, Y. F. et al. Features of whey protein concentrate supplementation in children with rapidly progressive HIV infection. Journal of Tropical Pediatrics, v. 52, n. 1, p. 34-38, 2005. PMid:16014759. http://dx.doi.org/10.1093/tropej/fmi074
MORR, C. V. et al. Collaborative study to develop a standardized food protein solubility procedure. Journal of Food Science, v. 50, n. 6, p. 1715-1718, 1985. http://dx.doi.org/10.1111/j.1365-2621.1985. tb10572.x

MOSMANN, T. Rapid colorimetric assay for cellular growth and survival: application to proliferation and cytotoxicity assays. Journal of Immunological Methods, v. 65, n. 1-2, p. 55-63, 1983. http:// dx.doi.org/10.1016/0022-1759(83)90303-4

PACHECO, M. T. B.; SGARBIERI, V. C. Effect of different hydrolysates of whey protein on hepatic glutathione content in mice. Journal of Medicinal Food, v. 8, n. 3, p. 337-342, 2005. PMid:16176144. http:// dx.doi.org/10.1089/jmf.2005.8.337

REEVES, P. G.; NIELSEN, F. H.; FAHEY, J. G. C. AIN-93. Purified diets for laboratory rodents: Final report of the American Institute of Nutrition Ad Hoc Writing Committee on the formulation of the AIN-76A rodent diet. Journal of Nutrition, v. 123, n. 11, p. 1939-1951, 1993.

ROSANELI, C. F. et al. Efficacy of a whey protein concentrate on the inhibition of stomach ulcerative lesions caused by ethanol ingestion. Journal of Medicinal Food, v. 5, n. 4, p. 221-228, 2002. PMid:12639397. http://dx.doi.org/10.1089/109662002763003375

ROSANELI, C. F. et al. Protective effect of bovine milk whey protein concentrate on the ulcerative lesions caused by subcutaneous administration of indomethacin. Journal of Medicinal Food, v. 7, n. 3, p. 309-314, 2004. PMid:15383224. http://dx.doi.org/10.1089/ jmf.2004.7.309

ROY, M. K. et al. Peptides from N-terminal end of lactoferrin induce apoptosis in human leukemic (HL-60) cells. Journal of Dairy Science, v. 85, n. 9, p. 2065-2074, 2001. http://dx.doi.org/10.3168/ jds.S0022-0302(02)74284-7

SAVILLE, B. A. A scheme for the colorimetric determination of microgram amounts of thiols. Food Chemistry, v. 83, n. 993, p. 670-673, 1958.

SGARBIERI, V. C. Propriedades fisiológicas-funcionais das proteínas do soro de leite. Brazilian Journal of Nutrition, v. 17, n. 4, p. 397-409, 2004.

SGARBIERI, V. C. The role of dietary energy and of macrocomponents of foods in modulating carcinogenesis (an overview). Ciência e Cultura, v. 51, n. 2, p. 104-121, 1999.

SGARBIERI, V. C.; FARFAN, J. A.; TANAKA, M. Response of rats amino acid supplementation of brown egg albumin. Journal of Nutrition, v. 103, n. 12, p. 1731-1738, 1973.

SONIS, S. T. et al. Prevention of chemotherapy-induced ulcerative mucositis by transforming growth factor $\beta$ 3. Cancer Research, v. 54, n. 5, p. 113-1138, 1994.

SPACKMAN, D. C., STEIN, W. H., MOORE, S. Automatic recording apparatus for use in the chromatography of aminoacids. Analytical Biochemistry, v. 30, n. 9, p. 1190-1206, 1958.

SVENSSON, M. et al. Conversion of alpha lactalbumin to a protein inducing apoptosis. Proceedings of the National Academy of Sciences, v. 97, n. 8, p. 4221-4226, 2000. http://dx.doi.org/10.1073/pnas.97.8.4221

TREITINGER, A. et al. Effect of N-acetyl-L-cysteine on lymphocyte apoptosis, lymphocyte viability, TNF- $\alpha$ and IL-8 in HIV-infected patients undergoing anti-retroviral treatment. Brazilian Journal of Infectious Disease, v. 8, n. 5, p. 363-370, 2004. PMid:15798812. http://dx.doi.org/10.1590/S1413-86702004000500005

VINDELOV, L. L.; CHRISTENSEN, I. J.; NISSEN, N. I. A detergenttrypsin method for the preparation of nuclei for flow cytometric DNA analysis. Cytometry, v. 3, n. 5, p. 323-327, 1983. PMid:6188586. http://dx.doi.org/10.1002/cyto.990030503

ZINSLY, P. F. et al. Produção piloto de concentrados de proteínas de leite bovino: composição e valor nutritivo. Brazilian Journal of Food Techonology, v. 4, n. 1, p. 1-8, 2001. 